\title{
Determinants of E-Government Development: Some Methodological Issues
}

\author{
Isabel-María García-Sánchez (Corresponding author) \\ Faculty of Business and Economics, Salamanca University \\ Campus Miguel de Unamuno, Edificio FES, 37007 Salamanca, Spain \\ Tel: +923-29-4400 ext. $3133 \quad$ E-mail: lajefa@usal.es \\ Beatriz Cuadrado-Ballesteros \\ Faculty of Business and Economics, Salamanca University \\ Campus Miguel de Unamuno, Edificio FES, 37007 Salamanca, Spain \\ Tel:+923-29-4400 ext. 3133 E-mail: cuadradoballesteros@gmail.com
}

José-Valeriano Frías-Aceituno

Faculty of Business and Economics, Granada University

Campus La Cartuja, s/n, 18071 Granada, Spain

Tel: +958-24-1000 ext. 20148 E-mail: jfrias@ugr.es

Received: April 11, $2012 \quad$ Accepted: May 20, $2012 \quad$ Published: June 30, 2012

doi: 10.5430/jms.v3n3p11 URL: http://dx.doi.org/10.5430/jms.v3n3p11

\begin{abstract}
Previous papers that have attempted to analyze the determinant factors of the implementation of e-government present serious limitations owing to multicollinearity and endogeneity problems.

In this line, the aim of this paper is to analyze the factors which promote the development of the electronic administration in the national governments of 192 countries worldwide by simultaneous equations in order to overcome the cited problems.

Our findings emphasize that there is a bidirectional relation between government effectiveness and the sophisticated online presence of the administration. Surprisingly, countries with higher economic and political resources available do not necessarily show greater e-government development than others.
\end{abstract}

Keywords: E-Government, Public Administration, New Public Management

\section{Introduction}

E-government is one of several reforms undertaken by public administrations in order to increase the transparency of public bodies (Pina et al., 2009) and citizen participation (Justice et al., 2006). At the same time, it is meant to improve efficiency and achieve significant cost reductions derived from the use of new and more efficient technologies (Kim, 2007; Tolbert et al., 2008).

Previous studies oriented to the analysis of the explanatory factors of e-government development present several divergences in relation to the determinants of the level of sophistication of the online presence of public administrations (West, 2000, 2001, 2002, 2003 and 2004; Laswad et al., 2005; Caba et al., 2005; Torres et al., 2005; Torres et al., 2006; Pina et al., 2007; Pina et al., 2009; Caba et al., 2008; Cárcaba and García, 2008; Gandía and Archidona, 2008).

These divergences may be caused by the multicollinearity (Note 1) and endogeneity (Note 2) problems. In this sense, a few papers (e.g., Srivastava and Teo, 2007; Singh et al, 2007) have attempted to solve these limitations by partial least squares estimation. However, this methodology is more suitable for categorical variables than for the numerical variables present in these studies. 
Thus, the main aim this paper is to seek the determinants of e-government development using a suitable methodology, concretely simultaneous equations, in order to avoid the above-mentioned limitations.

With this goal in mind, we adopt the explanatory framework proposed by Moon and Norris (2005), a broader one than that of Srivastava and Teo (2007), in which the level of e-government development is explained by institutional characteristics, government capacity and managerial innovation orientation.

Owing to the reduced number of studies focused exclusively on the analysis of the socioeconomic determinants of e-government development in the national public administrations (e.g., La Porte et al., 2002; Siau and Long, 2006; Kim, 2007), and owing to the advantages derived from the consideration of different geographical contexts, this study analyzes the determinants of e-government sophistication in the national administration of 192 countries worldwide.

Our findings show the existence of endogeneity problems between government effectiveness and digital administration. In addition, the results indicate that the development of digital administration is strongly linked to several institutional and democratic characteristics.

\section{E-Government, Government Effectiveness and Institutional Characteristics: Research Hypotheses}

Moon and Norris (2005) proposed an explanatory theoretical framework for e-government in which its adoption is determined by (i) an institutional variable, (ii) government capacity, and (iii) a managerial innovation orientation.

Firstly, institutional characteristics comprise the size of the government and the external pressures or demands for electronic-administration. These factors describe the technical and organizational environment that is strongly linked to the socioeconomic and cultural features of the population (Brudney and Selden, 1995; Moon and Norris, 2005).

In general, large governments are more likely to adopt e-government than small ones because they operate under greater pressure to find alternative ways to provide public services (Moon and Norris, 2005; Weare et al., 1999; Musso et al., 2000; West, 2001).

In addition, the external demands are also directly linked to the economic (Christiaens, 1999; Laswad et al., 2005; Siau and Long, 2006 and 2009; Kim, 2007; Tolbert et al., 2008) and cultural status of the population (Mossberger et al., 2006; Kim, 2007; Gandía and Archidona, 2008; Tolbert et al., 2008) as well as to the Internet diffusion proxy for technological capability (Kim, 2007; Tolbert et al., 2008).

According to previous statements, we have established the following hypothesis:

H1: Institutional characteristics positively influence the development of e-government.

However, there are serious collinearity problems among these factors, because the country's economic performance determines the cultural level of the population as well as the capacity for buying computers or technological devices and for accessing the Internet. Consequently, we have set up the second hypothesis of this study:

H2: Economic performance positively influences a country's cultural and technological capacities.

Secondly, government capacity reflects the economic and political resources available. As Moon and de Leon (2001) describe and Moon and Norris (2005) show, economic capacity is a resource-push-perspective, given that they have more resources available and a greater ability to generate other relevant ways to cover e-government development costs.

Politics plays an important role in public sector innovation and in e-government development. Several authors argue that the political stability necessary to implement the innovations proposed in an electoral program can significantly affect the development of the digital administration. Furthermore, the political competition and the possible benefits from an electronic administration can also influence its evolution (Tolbert et al., 2008; Cárcaba and García, 2008). According to these arguments, the third hypothesis has been established:

\section{H3: Government capacity positively influences the development of e-government.}

Finally, the managerial innovation orientation is a relevant factor to take into account in technological innovation processes. More concretely, the managerial innovation orientation captures the "institutional intention" (Moon and Norris, 2005), which can be defined as the level of government effort needed to reform the old bureaucracy towards a new public management. Hence, the governments oriented towards increasing efficiency and citizens satisfaction are more interested in developing e-government (Moon and Norris, 2005). Consequently, the following hypothesis has been formulated:

H4: Managerial innovation orientation positively influences the development of e-government.

However, La Porte (2005) observed the reverse relation. In other words, improvement in effectiveness is caused by more openness in web operations, but not the contrary. Thus, it also seems necessary to specify the following hypothesis: 


\section{H5: The development of e-government positively influences managerial innovation orientation.}

In this vein, politics plays an important role in public sector innovation and in e-government development. The dominant party affiliation of a legislative body can affect its development because contrary ideologies may defend different electronic administration styles. According to several authors, such as Ni and Bretschneider (2007), it can initially be thought that governments with a right-wing ideology tend to carry out programs or activities of a notably economic nature and they introduce public sector reforms, whereas those with other types of ideologies tend to concentrate on social policies more frequently. In this respect, we have established the last hypothesis of this study:

H6: A conservative political tendency of the ruling party positively influences government effectiveness and the development of e-government.

\section{Methodology}

\subsection{Population and Sample}

In order to achieve our research goals and for the reasons that we have synthesized in the Introduction section, we selected most countries worldwide as our target population.

The sample used refers to the 192 countries selected by the United Nations for the elaboration of the E-Government Survey 2008. The necessary information for the creation of the proposed variables was obtained from the World Handbook 2007 available on the CIA website (www.cia.gov).

\subsection{Variables}

The variable used to measure e-government development corresponds to the Web Measurement Index 2008, drawn up by the United Nations Organization in 2007. It is a numerical variable that identifies the levels of sophistication of a specific country's web presence, taking into consideration the development of infrastructure, presentation and access to contents, business reengineering, data management, security and citizen-customer management. It is represented by E-G.

In relation to institutional characteristics, we selected (i) public sector employees (SIZE) as an indicator of government size; (ii) Gross Domestic Product per capita (GDP) as economic wealth; (iii) Adult Literacy (AL), and the ratio of Internet per 100 users (INT) to represent cultural and technological capabilities. In order to explain variables AL and INT, additionally, we introduced three dummies that identify the basic industry of the country (agriculture, industry and services).

According to La Porte et al. (2002), economic institutional capacity is measured by the government expenditure relative to gross domestic product (Egdp). The variable STA, the percentage of votes achieved by the ruling political party in the last presidential elections, and PP, the number of political parties that are represented in the national Parliament, identify political capacity.

For government effectiveness, according to several authors such as La Porte (2005), the most suitable are the following World Bank Governance Indicators:

- Government effectiveness (GE). This encompasses certain issues such as the quality of public service provision, the quality of the bureaucracy, the competence of civil servants, the independence of the Civil Service from political pressures and the credibility of the government's commitment to policies (Kaufmann et al., 2008).

- Voice and accountability (VA). This points to the extent to which citizens can participate in the election of governments, media independence, etc.

- Political stability (PS). Perceptions of likelihood that the government will be destabilized, that insecurity will affect citizen's selection of governments.

- Control of corruption (CC). Perceptions of corruption about payments to get things done, political leader's actions, etc.

In order to represent political ideology, we use the dummy CONSER, a variable that takes the value 1 if the governing party shows a conservative ideology and 0 , otherwise.

\subsection{Analysis Technique}

Based upon the variables selected to test the proposed hypotheses, we have defined the following models:

E- $\mathrm{G}_{\mathrm{i}}=\beta_{0}+\sum_{\mathrm{i}=1}^{4} \beta_{\mathrm{i}} \mathrm{Ich}_{\mathrm{i}}+\sum_{\mathrm{i}=1}^{3} \partial_{\mathrm{i}} \mathrm{GC}_{\mathrm{i}}+\sum_{\mathrm{i}=1}^{4} \mu_{\mathrm{i}} \mathrm{MIO}_{\mathrm{i}}+\mu_{1} \mathrm{CONSER}_{\mathrm{i}}+\varepsilon_{\mathrm{i}}$

$\mathrm{AL}_{\mathrm{i}}=\beta_{0}+\sum_{\mathrm{i}=1}^{4} \beta_{\mathrm{i}} \mathrm{Ich}_{\mathrm{i}}+\varepsilon_{\mathrm{i}}$

$\mathrm{IP}_{\mathrm{i}} \beta_{0}+\sum_{\mathrm{i}=1}^{4} \beta_{\mathrm{i}} \mathrm{Ich}_{\mathrm{i}}+\varepsilon_{\mathrm{i}}$ 
$\mathrm{GE}=\beta_{0}+\beta_{1} \mathrm{E}_{-\mathrm{G}_{\mathrm{i}}}+\sum_{\mathrm{i}=1}^{3} \alpha_{\mathrm{i}} \mathrm{Ich}_{\mathrm{i}}+\sum_{\mathrm{i}=1}^{3} \partial_{\mathrm{i}} \mathrm{GC}_{\mathrm{i}}+\sum_{\mathrm{i}=1}^{3} \mu_{\mathrm{i}} \mathrm{MIO}_{\mathrm{i}}+\mu_{1} \mathrm{CONSER}_{\mathrm{i}}+\varepsilon_{\mathrm{i}}$

where,

Ich are the variables proposed to define the institutional characteristics in each country: SIZE, GDP, AL, INT, AGRI, INDU, SERV.

$G C$ are the variables which reflect the government's economic and political capacity: Egdp, STA and PP.

$M I O$ are the variables which represent the managerial innovation orientation: $G E, V A, P S, C C$.

i represents the countries considerate in the sample.

Models (1) to (4) have been estimated empirically through simultaneous equations, given the endogeneity and collinearity problems.

\section{Results of the Empirical Analysis}

\subsection{Previous Descriptive Analysis}

Table 1 shows the correlations among the proposed variables. We can observe the correlations are high, which suggests the endogeneity and multicollinearity problems that we cited.

\section{$<$ Table 1 about here $>$}

\subsection{Results of the Simultaneous Equations}

The findings from the four dependency models estimated by simultaneous equations are shown in Table 2 .

$<$ Table 2 about here $>$

Model 1, oriented to evidence the determinants of e-government development, has an explanatory power of $99.60 \%$ for a confidence level of $99 \%$ (p-value $<0.01$ ).

Six variables, SIZE, AL, GE, VA, CC and PS are statistically relevant for a confidence level of 99\%, except the last variable (PS), which is significant at $95 \%(0.01<$ p-value $<0.05)$. SIZE has a negative effect, and the other five variables have a positive impact on e-government development.

The rest of the variables also present a direct relation with the dependent variable E-G, except in the case of STA, for which the relation is inverse. However, none of them are relevant from the statistical point of view.

In relation to institutional characteristics, the only significant variables are SIZE and AL with a negative and positive impact on E-G, respectively. These results indicate that the effect of the institutional determinants on the e-government development is quite reduced, so we partially accept the hypothesis $\mathrm{H}$. Specifically, they indicate that small public administrations in countries with a more literate population have more pressure to development e-government.

All of the variables that were designed to test the influence of government capacities on the sophistication of e-government are non-relevant in the analysis. Therefore, we cannot accept the hypothesis H3.

In contrast, all the factors proposed for representing managerial innovation orientation have a relevant positive impact on the dependent variable E-G, as we expected. Since government effectiveness has a direct impact on e-government development, hypothesis H4 may be accepted.

These affirmations cannot be extended to a conservative political ideology and thus hypothesis H6 must be partially rejected.

Models 2 and 3 those are oriented to avoid collinearity problems between institutional characteristics, showed that the factors adult literate and internet penetration have been explained by the type of sectors that are predominant in the country. In this sense, countries in which agriculture is the most important sector exhibit lower levels of cultural and technological capabilities. In contrast, where the predominant sector is services, the above relation is inverse. Moreover, Internet penetration is explained by gross domestic product as well. Regarding these results, the hypothesis $\mathrm{H} 2$ may be accepted.

Model 4, estimated to avoid problems of endogeneity between e-government development and government effectiveness, has an explanatory power of $91.92 \%$ for a confidence level of $99 \%$.

Five variables, SIZE, E-G, AL, VA and CC, have a positive impact on government effectiveness for a confidence level of $99 \%$, except SIZE, whose effect is negative.

In this respect, the positive effect of e-government development, E-G, on government effectiveness allows us to accept the hypothesis H5. 
Again, a conservative political ideology does not influence government effectiveness so we cannot accept the hypothesis H6.

\section{Discussion of Results}

Regarding the problems mentioned above, that this paper has made an attempt to overcome, we have evidenced the existence of a bidirectional relation between e-government development and administration effectiveness. This evidence is conflicting with the findings of La Porte (2005), who obtained only a significant direct impact of the latter factor on the former.

In relation to collinearity problems, our results suggest that in the analysis of e-government development variables that represent the level of a population's culture and technological capabilities without introducing their economic level should be considered, since this last factor explains the previous ones.

Focusing on the determinant factors of the development of a digital administration, the findings evidence the significant role played by institutional characteristics and the managerial innovation orientation. In contrast, the public body capacity does not have any influence on this process.

In relation to institutional characteristics, in line with Kim (2007) and Tolbert et al. (2008), we have detected that a higher level of development of e-government is strongly linked to the external demands of people with higher levels of literacy skills, while the insignificant effect of technological development confirms the results of some papers as for example Pina et al. (2007), Kim (2007) and Gandía and Archidona (2008).

Government size has a negative influence on electronic administration development, in contrast to other studies (Pina et al., 2009; Gandía and Archidona, 2008). In this sense, other papers as García Sánchez and Prado-Lorenzo (2008) and Prado-Lorenzo and García-Sánchez $(2006,2009)$ have shown that larger administrations present several problems in the implementation of different innovations due to their complex organization.

In relation to managerial innovation orientation, better governance in terms of effectiveness and ethics is necessary, as well as an environment of political stability and significant civil liberties. Similar results have been found by a few previous papers, such as Kamarck (2004) and Kim (2007).

Regarding government capacity, and in respect to economic capacity, our results are quite different from the opinion posited by American public managers in Coursey and Norris' (2008) survey. However, they are similar to the results of La Porte et al. (2002) for worldwide countries, Pina et al. (2009) for European municipalities and Tolbert et al. (2008) for US states. Relating to political capacity, our findings are related to Laswad et al. (2005), who conclude that it is not a statistically relevant factor for New Zealand municipalities. Moreover, as Gandía and Archidona (2008) showed for Spanish municipalities, we have not detected a significant relation between the economic and political institutional capacity and the level of development of websites of national administrations independently of their economic status. These results are particularly surprising, because the availability of these kinds of resources notably influences the implementation of reforms in public administration (UNPAN, 2007).

Political factors do not have any impact on dependent variables, and concretely, on the electronic administration development. This means that national governments around the world are widely concerned about the need for fostering an electronic administration. This backing can be seen in the political programs from different ideologies, which means that it can be developed without delay due to a lack of political stability or the existence of economic problems.

\section{Conclusions}

In this paper we have tried to establish the determinants of the level of development of national administrations' websites from 192 countries, using a more suitable econometric methodology.

The results reveal that the sophistication of the electronic administration runs parallel to the existence of a higher cultural status of the population as well as an evolution toward ethical and stable democracies. Furthermore, we have detected an absence of any relation between the economic and political capacity of central government and the level of technological innovation in its online presence.

Methodologically, we tested the existence of a bidirectional relation between e-government development and administration effectiveness. This new evidence means that in future studies researchers should consider the endogeneity problem by means of more sophisticated dependence models as simultaneous equations or instrumental variables.

In relation to collinearity problems, our results suggest that it is necessary to consider variables that represent the level of a population's culture and technological capabilities without introducing their economic level in the analysis of e-government development. 
Regarding future lines of research, it would be interesting to undertake an analysis of the level of development of central governments' websites with the aim of overcoming the metrical limitations of the UN e-government survey, thereby providing our findings with more robustness.

\section{References}

Brudney, J. \& Selden, S. (1995) The Adoption of Innovation by Smaller Local Governments: The Case of Computer Technology. American Review of Public Administration, 25, 71-86. http://dx.doi.org/10.1177/027507409502500105

Caba, C., López, A.M. \& Rodríguez, M.P. (2005) Citizens' access to on-line governmental financial information: Practices in the European Union Countries. Government Information Quarterly, 22, 258-276. http://dx.doi.org/10.1016/j.giq.2005.02.002

Caba, C., Rodríguez M.P. \& López, A.M. (2008) E-Government process and incentives for online public financial information. Online Information Review, 32, 379-400. http://dx.doi.org/10.1108/14684520810889682

Cárcaba, A. \& García, J. (2008) Determinantes de la divulgación de información contable a través de Internet por parte de los gobiernos locales. Revista Española de Financiación y Contabilidad, 137, 63-84.

Coursey, D. \& D.F. Norris. (2008) Models of E-government: Are they correct?: An empirical assessment. Public Administration Review, 68, 523-536. http://dx.doi.org/10.1111/j.1540-6210.2008.00888.x

Christiaens, J. (1999) Financial accounting reform in Flemish municipalities: An empirical investigation. Financial Accountability \& Management, 15, 21-40. http://dx.doi.org/ 10.1111/1468-0408.00072

Esteves, J. \& Rhoda, J. (2008) A comprehensive framework for the assessment of eGovernment projects. Government Information Quarterly, 25, 118-132. http://dx.doi.org/10.1016/j.giq.2007.04.009

Gandía, J.L. \& Archidona, M.C. (2008) Determinants of web site information by Spanish city councils. Online Information Review, 32, 35-57. http://dx.doi.org/10.1108/14684520810865976

Justice, J.B., Melitski, J. \& Smith, D.L. (2006) E-Government as an instrument of fiscal accountability and responsiveness: Do the best practitioners employ the best practices?. American Review of Public Administration, 36, 301-322. http://dx.doi.org/10.1177/0275074005283797

Kamarck, E.C. (2004) Government innovation around the world. Working Paper Series: RWP04-101. John F. Kennedy School of Government. Harvard University.

Kaufmann, D., Kraay A. \& Mastruzzi, M. (2008) Governance matters VII: Governance indicators for 1996-2007. [Online] Available: http://www.worldbank.org (October, 2008).

Kim, Ch.K. (2007) A cross-national analysis of global E-government. Public Organization Review, 7, 317-329. http://dx.doi.org/10.1007/s11115-007-0040-5

Laswad, F., Fisher R. \& Oyelere. P. (2005) Determinants of voluntary Internet financial reporting by local government authorities. Journal of Accounting and Public Policy, 24, 101-121. http://dx.doi.org/10.1016/j.jaccpubpol.2004.12.006

La Porte, T.M. (2005) Being Good and Doing Well: Organizational Openness and Government Effectiveness on the World Wide Web. Bulletin of the American Society for Information Science and Technology, 51(5), 23-27. http://dx.doi.org/10.1002/bult.1720310310

La Porte, T.M., Demchak, H.C., Jong M. \& Friis, Ch. (2002) Democracy and Bureaucracy in the Age of the Web: Empirical Findings and Theoretical Speculations. Administration \& Society, 34 (3), 411-446. http://dx.doi.org/10.1177/0095399702034004004

Moon, M.J. \& de Leon, P. (2001) Municipal Reinvention: Managerial Values and Diffusion among Municipalities. Journal of Public Administration Research and Theory, 11, 327-352.

Moon, M.J. \& Norris, D.F. (2005) Does managerial orientation matter? The adoption of reinventing government and e-government at the municipal level. Information System Journal, 15, 43-60. http://dx.doi.org/10.1111/j.1365-2575.2005.00185.x

Mossberger, D., Tolbert, C.J. \& Gilbert, M. (2006) Race, Place, and Information Technology. Urban Affairs Review, 41(5), 583-620. http://dx.doi.org/10.1177/1078087405283511

Musso, J., Weare C. \& Hale, M. (2000) Designing Web Technologies for Local Governance Reform: Good Management 
or Good Democracy. Political Communication, 17, 1-19. http://dx.doi.org/10.1080/105846000198486

Nemec, J. \& Kolisnichenko, N. (2006) Market-based Health Care Reforms in Central and Eastern Europe: Lessons after ten years of change. International Review of Administrative Sciences, 72(1), 11-20. http://dx.doi.org/10.1177/0020852306061611

Ni, A.Y. \& Bretschneider, S. (2007) The decision to contract out: A study of contracting for e-government services in $\begin{array}{lllll}\text { state governments. } \quad \text { Public } & \text { Administration }\end{array}$ http://dx.doi.org/10.1111/j.1540-6210.2007.00735.x

Pina, V., Torres, L. \& Royo, S. (2007) Are ICTs improving transparency and accountability in the EU regional and local governments?: An empirical study. Public Administration, 85, 449-472. http://dx.doi.org/10.1111/j.1467-9299.2007.00654.x

Pina, V., Torres, L. \& Royo, S. (2009) E-government evolution in EU local governments: a comparative perspective. Online Information Review, 33(6), 1137-1168. http://dx.doi.org/10.1108/14684520911011052

Rodríguez, M.P., Caba, C. \& López, A.M. (2005) Cultural contexts and governmental digital reporting. International Review of Administrative Sciences, 72, 269-290. http://dx.doi.org/10.1177/0020852306064614

Siau, K. and Long, Y. (2006) Using social development lenses to understand E-government development. Journal of Global Information Management, 14, 47-62. http://dx.doi.org/10.4018/jgim.2006010103

Siau, K. \& Long, Y. (2009) Factors impacting e-government development, Journal of Computer Information System, Fall, 98-107.

Singh, H., Das, A. \& Joseph, D. (2007) Country-level determinants of e-Government maturity, Communications of the Association for Information Systems, Atlanta.

Srivastava, S.C. \& Teo, T.S.H. (2007) What facilitates e-government development? A cross-country analysis? Electronic Government, An International Journal, 4(4), 365-378. http://dx.doi.org/10.1504/EG.2007.015034

Tolbert, C.J., Mossberger, K. \& McNeal, R. (2008) Institutions, Policy Innovation and E-government in the American States. Public Administration Review, 68, 549-563. http://dx.doi.org/10.1111/j.1540-6210.2008.00890.x

Torres, L., Pina, V. \& Royo, S. (2005) E-government and the transformation of public administrations in EU countries: Beyond NPM or just a second wave of reforms?. Online Information Review, 29, 531-553. http://dx.doi.org/10.1108/14684520510628918

Torres, L., Pina, V. \& Acerete, B. (2006) E-governance developments in European Union cities: Reshaping government's relation with citizens. Governance: An International Journal of Policy, Administration, and Institutions, 19, 277-302. http://dx.doi.org/10.1111/j.1468-0491.2006.00315.x

United Nations (2008) World Public Sector Report 2008. E-government survey. New York, NY: United Nations.

UNDP. (2008) Supporting UNCAC Implementation: Country Experiences in the Asia-Pacific Region. United Nations Development Programme.

UNPAN (2007) Rethinking Public Administration: an Overview, Division for Public Economics and Public Administration. United Nations.

Weare, C., Musso, J. \& Hale, M. (1999) Electronic Democracy and the Diffusion of Municipal Web Pages in California. Administration and Society, 31, 3-27. http:/dx.doi.org/10.1177/009539999400935475

West, D. (2000) State and federal E-government in the United States 2000. [Online] Available: http://www.insidepolitics.org/policyreports.html, accessed May 2008.

West, D. (2001) State and federal E-government in the United States 2001. [Online] Available: http://www.insidepolitics.org/policyreports.html (May, 2008).

West, D. (2002) State and federal E-government in the United States 2002. [Online] Available: http://www.insidepolitics.org/policyreports.html (June, 2008).

West, D. (2003) State and federal E-government in the United States 2003. [Online] Available: http://www.insidepolitics.org/policyreports.html (June, 2008).

West, D. (2004) E-government and the transformation of service delivery and citizen attitudes. Public Administration Review, 64, 15-27. http://dx.doi.org/10.1111/j.1540-6210.2004.00343.x 
Notes

Note 1. Singh et al. (2007) showed that Gross Domestic Product, a variable usually employed to identify the economic level of populations, determines the technological infrastructure, human quality and governance quality. Studies, in general, introduce all of these variables jointly. La Porte et al (2002) were the only authors to estimate stepwise dependence models in order to prevent this problem.

Note 2. E.g., several authors affirm that the development of e-government involves a previous rationalization of the internal administrative processes and public services (Torres et al., 2005; Esteves and Rhoda, 2008), and thus incorporated variables representative of government effectiveness. On the other hand, La Porte (2005) observed that e-government is the factor that drives administration effectiveness. 
Table 1. Bivariate correlations

\begin{tabular}{|c|c|c|c|c|c|c|c|c|c|c|c|c|c|c|c|c|}
\hline$\therefore$ & E-G. & SIZE. & GDP. & $\mathbf{A L}$ & INT. & AGRI & INDU. & SERV & Egdp & PP. & STA. & GE. & Ps. & $\mathbf{V a}$ & $\mathrm{CC}_{.1}$ & CONSER \\
\hline E-G. & $\therefore$ & $\therefore$ & $\therefore$ & $\therefore$ & $\therefore$ & $\therefore$ & $\therefore$ & $\therefore$ & $\therefore$ & $\therefore$ &. & .1 & $\therefore$ & $\because$ & $\therefore$ & $\therefore$ \\
\hline SIZE & .134. &. &. &. &. & י. &. &. & $\therefore$ &. & $\therefore$ & $\therefore$ & $\therefore$ &. & $\therefore$ &. \\
\hline GDP & $.369^{* *}$ & -.046 & $\therefore$ & $\therefore$ & $\therefore$ & $\therefore$ & $\therefore$ & $\therefore$ & $\therefore$ & $\therefore$ & $\therefore$ & $\therefore$ & $\therefore$ & $\therefore$ & $\therefore$ & $\therefore$ \\
\hline $\mathbf{A L}$ & $.564^{* *}$ & .003. & $.297^{* *}$ & $\because$ & $\therefore$ & $\therefore$ & $\therefore$ & $\therefore$ & $\therefore$ & $\therefore$ & $\therefore$ & $\because$ & $\therefore$ & $\because$ & $\therefore$ & $\therefore$ \\
\hline INT. & $.687^{* *}$ & -.043 & $.452^{* *}$ & $.513^{* 8}$ & $\therefore$ & $\therefore$ & $\therefore$ & $\therefore$ & $\therefore$ & $\therefore$ & $\therefore$ & $\therefore$ & $\therefore$ & $\because$ & $\therefore$ & $\therefore$ \\
\hline AGRI & $-406^{* *}$ & $.147^{*}$. & $-338 * *$ & $-309 * *$ & $\begin{array}{l}.495^{* *} \\
\end{array}$ & י. & י. & י. & י. & י. & י. & י. & . & י. & י. & י. \\
\hline INDU. & .014. & -.016 & .033. & .021. & .025. & .055. & $\therefore$ & .1 &. & .1 &. &. & $\therefore$ &. &. &. \\
\hline SERV. & $.533^{* *}$ & -.080 & $.273^{* *}$ & $.458 * *$ & $.478^{* *}$ & $.427^{* *}$ & -.134 &. &. & י. & . & $\therefore$ & . &. & $\therefore$ & י. \\
\hline Egdp. & $.358^{* *}$ & $.157^{*}$. & $.175^{*}$ & $.169^{*}$ & $.342^{* *}$ & -.130. & -.042 .7 & $.151^{*} \cdot 1$ & .1 &. & י. &. &. &. & י. & $\therefore$ \\
\hline PP. & .131. & $.226^{* *}$ & -.049 & -.022 .1 & .069. & .141. & -.126 & -.005. & .029. & $\therefore$ & $\therefore$ & $\therefore$ & $\therefore$ & $\therefore$ &. &. \\
\hline STA. & $\begin{array}{l} \\
.343^{* 8}\end{array}$ & -.049 & -.134 & $.204^{* *}$ & $.382^{* *}$ & $.237^{* *}$ & $\begin{array}{l}-153^{*} . \\
\end{array}$ & -109 & -.090 .1 & $\begin{array}{l}- \\
.224^{* *}\end{array}$ & י & י. & י. & י. & י. & י. \\
\hline GE. & $.731^{* 8}$ & .010 & $.472^{* *}$ & $.524^{* 8}$ & $.811^{* 8}$ & $.471^{* *}$ & .054 & $.509^{* *}$ & $.270^{* 8}$ & .067. & $\begin{array}{l}- \\
.279 * * \\
\end{array}$ & י. & . & $\therefore$ & י. & . \\
\hline PS. & $.328^{* *}$ & $-.150^{*}$ & $.355^{* *}$ & $.275^{* *}$ & $.556^{* *}$ & $-448^{* *}$ & -.005. & $.344^{* *}$ & .121. & -.131. & -.131 & $.672^{* *}$ &. & י. & י. & י. \\
\hline VA. & $.452^{* *}$ & -.096 & $.355^{* *}$ & $.211^{* *}$ & $.574^{* *}$ & $.440^{* *}$ & -099. & $.454^{* *}$ & $.239 * *$ & $.191^{* *}$ & $251^{* *}$ & $.701^{* *}$ & $.660^{* *}$ & י. & י. & $\therefore$ \\
\hline $\mathrm{CC}$. & $.655^{* *}$ & -.075 & $.478 * *$ & $.442^{* *}$ & $.808^{* *}$ & $.481^{* *}$ & .041. & $.441^{* *}$ & $.267^{* *}$ & .069. & $294^{* *}$ & $.940^{* *}$ & $.706^{* *}$ & $.715^{* *}$ & י. & י. \\
\hline CONSER & $.430^{* *}$ & .000. & $.400^{* *}$ & $.231^{* 8}$ & $.427^{* 8}$ & $240^{* *}$ & -.096. & $.262^{* *}$ & $.302^{* *}$ & .091. & $-.164^{*}$ & $.438^{* *}$ & $.310^{* *}$ & $.415^{* *}$ & $.448^{* *}$ & י. \\
\hline
\end{tabular}

E-G: e-government development; SIZE: public employess; GDP: gross domestic product per capita; AL: adult literate; INT: internet per 100 users; Egdp: government expenditures relative to GDP; STA: percentage of votes achieved by the ruling political party in the last presidential elections; PP: the number of political parties that are represented in the national Parliament; GE: government effectiveness; VA: voice and accountability; PS: political stability; CC: control of corruption; CONSERV: variable that takes the value 1 if the governing party shows a conservative ideology and 0 , otherwise; AGRI: dummy that identify if the agriculture sector is the predominant sector in the country; INDU: dummy that identify if the industry sector is the predominant sector in the country; SERV: dummy that identify if the services sector is the predominant sector in the country 
Table 2. Simultaneous Equations

\begin{tabular}{|c|c|c|c|c|c|c|c|c|c|c|c|c|}
\hline . & \multicolumn{3}{|l|}{ Model $1 .}$. & \multicolumn{3}{|l|}{ Model 2.1 } & \multicolumn{3}{|l|}{ Model 3.. } & \multicolumn{3}{|l|}{ Model 4.} \\
\hline \multirow[t]{2}{*}{$\therefore$} & \multicolumn{3}{|l|}{ E-G. } & \multicolumn{3}{|l|}{$\mathrm{AL}$} & \multicolumn{3}{|l|}{ INT., } & \multicolumn{3}{|l|}{$\mathrm{GE}_{1 .}$} \\
\hline & Coef. 1 & Std.Err... & $z$. & Coef. 1 & Std. Err... & Z.r & Coef.: & Std.Err... & $z$. & Coef.:-1 & Std.Err... & $z$. \\
\hline Constant. & 1.226617 & .2866329 & 4.28 & 6.974697. & 3.065856 & $22.75^{* \pi \hbar}$ & 1.567353 & 3.121496 & $5.02^{* \pi *}$ & .3768445 & 1310919. & $2.87^{* \pi *}$ \\
\hline E-G. &. & י. & י. & י. &. &. &. &. &. & \begin{tabular}{|c|}
949865 \\
\end{tabular} & .2552569 & $3.86^{* \pi *}$ \\
\hline $\begin{array}{l}\text { SIZE. } \\
\text {. }\end{array}$ & $-5.43 e-10$ & $2.07 \mathrm{e}-10$ & $-2.62^{* * * *}$ & . & $\therefore$ &. & $\therefore$ & $\therefore$ & $\therefore$ & $-5.78 \mathrm{e}-10$ & $1.59 \mathrm{e}-10$ & $-3.63^{i \dot{*} x}$ \\
\hline GDP.r & $9.59 e-07$. & $8.12 \mathrm{e}-07$. & 1.18. & .0000805 & . & 1.51 .7 & .0001804 & . 0000539 & $3.35^{i \dot{*}}$ & $3.39 \mathrm{e}-07$. & $9.80 \mathrm{e}-07$. & 0.35. \\
\hline $\mathrm{AL}$. & . 0107784 & .0031472 & $3.42^{* \pi *}$ & $\therefore$ &. &. & . &. & י. & . & ו.0026919. & $4.01^{* \pi *}$ \\
\hline INT.: & ו.0042861. & . & $0.67 .$, & י. &. &. &. &. &. & $\therefore$ & . &. \\
\hline Egdp. & $2.74 \mathrm{e}-07$. & $1.67 \mathrm{e}-07.1$ & 1.65. & $\therefore$ &. &. &. & $\therefore$ & $\therefore$ & $2.06 \mathrm{e}-07$. & $1.57 \mathrm{e}-07$ & 1.31. \\
\hline STA. & -.001591. & .0011472 & -1.39. & י. & $\therefore$ & $\therefore$ & י. &. &. & -.0008965 & .0011515. & -0.78. \\
\hline $\mathrm{PP}$. & I.0048498. & . 0072497 & 0.67. & . &. & $\therefore$ & י. & $\therefore$ & י. & .0043938. & .0090182. & 0.49. \\
\hline$\overline{\mathrm{GE}}$. & 1.226715 & .2485588 & $4.94^{* \pi *}$ & . & י. & $\therefore$ & י & $\therefore$ & $\therefore$ & . & . & . \\
\hline VA. & . 1210065 & ו & $3.46^{\dot{*} * \dot{*}}$ & $\therefore$ & $\therefore$ & $\therefore$ &. & $\therefore$ &. & \begin{tabular}{|l}
1087833 \\
\end{tabular} & .0371911. & $2.92^{* * \pi}$ \\
\hline PS., & י.0599323 & . & $1.90^{* *}$ & $\therefore$ & $\therefore$ & $\therefore$ & $\therefore$ &. & $\therefore$ & .031082. & .0390093. & 0.80. \\
\hline $\mathrm{CC}$. & ו.7876083 & .1547712 & $5.09^{* \star *}$ & $\therefore$ & $\therefore$ & $\therefore$ &. & $\therefore$ & $\therefore$ & .6742151 & .0453341. & $14.87^{* \pi *}$ \\
\hline CONSER & . & י. & $0.91 .$. & .1 & .1 &. & .1 & .1 &. & \begin{tabular}{|c|}
.0317945. \\
\end{tabular} & .0692917 .1 & 0.46. \\
\hline AGRI. & $\therefore$ & $\therefore$ &. & -8.379541 & 3.148094 & $-2.66 * x$ & -151.215 & 3.178595 & $-4.76^{* * \pi}$ &. & י & $\therefore$ \\
\hline INDU. & .1 &. & י. & 8.071028. & 6.306854. & 1.28. & 2.650523 & 5.960331. & 0.44 &. & 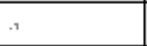 &. \\
\hline SERV .1 & $\therefore$ & $\therefore$ & $\therefore$ & 2.169082 & \begin{tabular}{|l}
3.140293 \\
\end{tabular} & $6.91^{* * *}$ & 1.376149 . & 3.179988 & $4.33^{* \pi *}$ &. & $\therefore$ &. \\
\hline .1 &. & $\therefore$ & $\therefore$ & $\therefore$ &. & .1 &. & $\therefore$ & .1 &. & $\therefore$ & $\because$ \\
\hline R-sq. &. & 0.996 & $\therefore$ & $\therefore$ & 0.4007. & $\therefore$ & $\therefore$ & 0.4241. & $\therefore$ & $\therefore$ & 0.9192 &. \\
\hline Chi-sq.-. & .9 & $228.71^{* \pi \hbar}$ & $\therefore$ &. & $100.01^{* \star *}$ &. &. & $110.77^{* * \pi}$ &. &. & $1863.36^{* \star \pi k}$ & $\therefore$ \\
\hline held & mificant $c$ & fficients.। & & & & & & & & & & \\
\hline
\end{tabular}

E-G: e-government development; SIZE: public employees; GDP: gross domestic product per capita; AL: adult literate; INT: internet per 100 users; Egdp: government expenditures relative to GDP; STA: percentage of votes achieved by the ruling political party in the last presidential elections; PP: the number of political parties that are represented in the national Parliament; GE: government effectiveness; VA: voice and accountability; PS: political stability; CC: control of corruption; CONSERV: variable that takes the value 1 if the governing party shows a conservative ideology and 0 , otherwise; AGRI: dummy that identifies whether the agriculture sector is the predominant sector in the country; INDU: dummy that identifies whether the industry sector is the predominant sector in the country; SERV: dummy that identifies whether the services sector is the predominant sector in the country. 